Айхан Ханкиши оглы Рустамзаде orcid.org/0000-0001-5211-8359

доктор юридических наук,

заведующий кафедрой правоведения

Национальной академии авиащии Азербайджана

Эльшад Эльдар оглы Гасанов orcid.org/0000-0001-5211-8359

кандидат юридических наук,

докторант на соискание ученой степени доктора наук

Института права и прав человека

Национальной академии наук Азербайджана

\title{
ИСТОРИЧЕСКИЕ АСПЕКТЫ СТАНОВЛЕНИЯ И РАЗВИТИЯ ПАРЛАМЕНТАРИЗМА
}

Введение. Из истории и теории государства и права известно, что в целом каждый конкретный правовой институт имеет определенную историю становления и развития. Это можно отнести к институту парламента, который является одним из важнейших институтов права и прошел уникальный путь исторического развития. При исследовании Милли Меджлиса Азербайджанской Республики как законодательного института важно использовать метод исторического подхода.

Основная цель исследования заключается в изучении истории становления и развития парламентаризма в Азербайджане.

Методы. При написании исследования использовались системный анализ, исторический подход к обобщению нормативных научно-практических материалов и другие методы. С помощью общенаучных и частнонаучных методов авторы последовательно проанализировали данные.

Обзор последних публикаций. Рассматривая работы, проведенные рядом исследователей поэтой теме, можно обратить внимание на следующее. С.А. Мирзаев отмечает, что, хотя деятельность парламента в государственном устройстве Азербайджана оценивается с разных исторических, правовых и политических аспектов, в целом ему отводится особая роль в процессе государственного строительства. Чтобы полностью понять место парламента Азербайджана в обществе и его роль в государственном управлении, необходимо рассмотреть вопрос о развитии парламентаризма в стране.

По мнению Т. Исламова, традиции парламентаризма в Азербайджане уходят корнями в развитие этого института в России, соответствуют исторической хронике, когда создавался первый парламент в царской России - Государственная Дума. Несмотря на то, что история парламентаризма в Азербайджане не такая многовековая, как в ряде европейских стран, в течение этого столетия она обогатилась своими национальными особенностями и политическим разнообразием.
Представление основного материала. Несмотря на то, что написано достаточное количество научных работ, касающихся истории государств, созданных и действующих на территории Азербайджана, все еще существует необходимость в фундаментальном исследовании его традиций, государственности древнего и раннесредневекового периодов, проблем управления обществом и государством, законотворчества и вопросов законодательства, а также истории политических и правовых учений [16, с. 3].

В начале I тысячелетия до н.э. в бассейне озера Урмия возникло государство Манна с более совершенным государственным устройством и органами управления. В отличие от классических рабовладельческих государств, власть главы государства в Манна ограничивалась советом старейшин, который являлся остатком племенной структуры [14, с. 11-20]. Правители Манна управляли страной с советом и помощью Совета старейшин. Правитель консультировался с Советом старейшин, прежде чем принять решение по какому-либо важному делу. Этот факт свидетельствует о том, что в азербайджанской государственности издревле существовала культура консультирования [9, с. 22]. И.М. Дьяконов $[15$, с. 82] сравнивает Совет старейшин штата Манна с "Советом Буле» в древних Афинах и «Сенатом» в Древнем Риме и характеризует эти органы как по существу близкие, похожие организации. Как видно, исторические корни становления парламента и традиции народного представительства в Азербайджане уходят вглубь веков.

Как известно из истории, государство Манна вошло в состав государства Мидии, затем стало частью государства Ахеменидов. Позже территория исторического Азербайджана вошла в империю Александра Македонского. Однако после его смерти в 323 году до н.э. империя распалась, в результате чего на юге Азербайджана образовалось государство Атропатена и Албания на севере. 
Несмотря на то, что власть правителя Атропатены была неограниченной, при правителе существовал Консультативный совет, состоящий из дворян и священников, с которым правитель консультировался при принятии решений. Такой совет существовал и в государстве Албания.

Во времена Хулагуидов и Джелаиридов верховным органом власти являлся гурултай (съезд), участие в котором было обязательным. Обсуждаемые вопросы решались участием большинства представителей и их голосов. На съездах оценивалась годовая деятельность государства. Количество участников съезда варьировалось в зависимости от обсуждаемых вопросов [13, с. 311-313].

В отличие от некоторых европейских стран, в средние века в Азербайджане не было отдельной законодательной власти. Указы, занимавшие особое место среди источников права Азербайджана, были принимаемые в те времена как многочисленные нормативные акты. При принятии указов шаха по его же приказу созывалось собрание для обсуждения проекта документа. На собрание приглашались высокопоставленные религиозные деятели, влиятельные ветераны и члены Верховного Дивана.

После широкого обсуждения проекта указа он записывался лицом, уполномоченным шахом. Затем мастером-каллиграфом создавалась копия этого документа и представлялась шаху для подтверждения им печатью. Подтвержденный печатью шаха документ пересылался улему для ознакомления. В знак согласия он ставил свою печать под печатью шаха. На последней странице указа обязательно должно было быть имя издавшего его правителя. После утверждения указов шахом и духовенством, регистрации в канцелярии и диване их отправляли на места для исполнения [6, с. 74-84]. Несмотря на то, что указы были выражением воли шаха, они не являлись актами, принятыми им на авторитарной основе. То есть при принятии этих указов использовались консультативные процедуры, характерные для принятия современных законов.

В период правления Сефевидов консультативным органом центрального правительства был Верховный меджлис («Меджлиси-Ала»). Особые вопросы, представляющие государственную значимость, обсуждались в Мажлиси-Ала, состоящем из 12 членов. Однако последнее слово было за шахом, решения принимались на его основе. $\mathrm{y}$ шаха была неограниченная власть объявлять войну, заключать мир, подписывать договоры и изменять законы страны. В этих вопросах перед ним не было никаких препятствий [5, с. 49].

Деятельность Государственного совета, учрежденного Надир-шахом для управления государственными делами и принятия решений, носила формальный характер. В период ханства власть была основана на монархии. Во главе ханства стоял хан с неограниченной законодательной, исполнительной и судебной властью. В таких ханствах, как Шекинское, Ширванское, Карабахское и Губинское при хане действовал Диван или Ханский Совет, которые состояли из важных правительственных чиновников и играли консультативную роль. Тем не менее, позиция Дивана или Совета ханов могла влиять на принятие решения [1, с. 17-18]. В некоторых ханствах были особые составители законов. $K$ примеру, во время правления Мухаммед-Хасан хана в Шекинском ханстве был составлен сборник законов под названием «Дастур аль-амаль» $[9$, с. 34]. Однако этот редкий документ не сохранился до наших дней.

Как справедливо отмечает С.А. Мирзаев, хотя деятельность парламента в государственном устройстве Азербайджана оценивается с разных исторических, правовых и политических аспектов, в целом ему отводится особая роль в процессе государственного строительства. Чтобы полностью понять место парламента Азербайджана в обществе и его роль в государственном управлении, необходимо рассмотреть вопрос о развитии парламентаризма в стране.

Парламентаризм Азербайджана не ограничивается одной конституционной нормой. История реального парламентаризма в Азербайджане шире, чем парламентаризм, определяемый конституционными нормами [11, с. 40]. Как отмечает Т. Исламов, традиции парламентаризма в Азербайджане уходят корнями в развитие этого института в России, соответствуют той же исторической хронике, когда создавался первый парламент в царской России - Государственная Дума. Несмотря на то, что история парламентаризма в Азербайджане не такая многовековая, как в ряде европейских стран, в течение этого столетия она обогатилась своими национальными особенностями и политическим разнообразием. Зарождение традиции национального парламентаризма, ее всестороннее формирование в духе государственности и патриотизма относится главным образом к началу XX века. Парламенты, избранные и созданные в Азербайджане, прошедшие несколько иной по сравнению с другими странами путь становления, смогли занять особое место среди мусульманских стран. Сформировавшись и воспользовавшись своим историческим опытом, парламент Азербайджана смог усилить свое влияние в вопросах интеграции с парламентами других стран [7, с. 42].

Несмотря на то, что азербайджанский парламентаризм молод, было бы неправильно думать, что он создавался на пустом месте. Безусловно, не стоит говорить о реальной независимости законодательного и представительного органа, существовавшего в советский период, когда все важ- 
ные вопросы решались партийно-государственной элитой страны, отвергался «буржуазный парламентаризм», а также отрицались такие ценности, как западная демократия, теория распределения правительства. Наряду с этим принципы современного государства и права, прежде всего, принцип историчности, направляют на изучение любой проблемы в период ее развития.

Краткая история важнейшего значения парламента в системе государственных органов показывает, что Азербайджан имеет определенный опыт в изучении основных принципов парламентаризма и ряда специальных вопросов. Так, в советский период в Азербайджане и других союзных республиках частично учитывались особенности современного парламентаризма, стабилизировались традиции, связанные с такими вопросами, как функционирование коллегиальных законодательных органов, организация их работы, законодательный процесс и другие [10, с. 92-97]. Несмотря на то, что классовый подход к политическим и правовым вопросам является обязательным, нельзя отказаться от всех исследований конституционного устройства и права того периода, руководствуясь только идеологическими соображениями.

На протяжении столетия нашему народу довелось жить в соответствии с законами, принятыми парламентами, действующими под разными названиями. По времени и политическому характеру нынешнего века парламент Азербайджана можно разделить на три группы: парламенты, образованные во времена Первой Российской империи (Дума); парламенты, созданные в советское время, и парламенты периода независимости [12]. Однако подобное разделение неполное, потому что парламент Азербайджанской Демократической Республики не нашел здесь своего отражения, несмотря на то, что в тот период XX века он функционировал, хоть и непродолжительное время.

Как известно из истории, 6 августа 1905 года Дума была учреждена как представительный орган на основании манифеста, подписанного российским царем Николаем II. Через несколько месяцев ей был дан статус законодательного органа. Дума была избрана сроком на 5 лет. Согласно закону о выборах, только 25 миллионов человек в Российской Империи с населением более 116 миллионов имели право голоса, которое в основном было предоставлено социально высшим слоям населения. Женщины, вместе с рабочим классом, этого права были лишены.

Чтобы избежать глубокого военно-политического и экономического кризиса в начале XX века Российская империя вступила в период реформ. Азербайджанская интеллигенция при поддержке великого филантропа Х.З. Тагиева с 1905 года представляла турецко-мусульманское население в центральных органах власти империи, которое боролось за устранение дискриминации и ограничений в этой сфере. В результате напряженной и активной деятельности в 1906 году в новый парламент России - Первую Государственную Думу - были избраны известные азербайджанские депутаты, которые, выступая с трибуны Госдумы, открыто критиковали политику геноцида Российской империи на Южном Кавказе, дискриминацию нашего народа, политику переселения, беззаконие целого народа, порабощение, защищали интересы не только азербайджанцев, но и всех российских мусульман. Несмотря на существующие ограничения в участии в Думе, необходимо отметить, что подавляющее большинство представленных в Думе азербайджанских интеллектуалов были правоведами, обладающими достаточным опытом в области законодательства, а также функций представительных органов, что внесло большой вклад в эффективность работы парламента, созданного во времена Народного фронта.

В 1918-1920 годах в Азербайджане начинается история парламентаризма в современном понимании, которая связана с образованием и деятельностью Азербайджанской Демократической Республики. 20 ноября 1918 года Национальный совет принял Закон «О Парламенте Азербайджанской Республики», согласно которому представители политических партий и всех проживающих в Азербайджане национальных меньшинств должны были быть представлены в однопалатном парламенте из 120 депутатов.

Обращаясь же к современному периоду, можно отметить, что Конституционным актом о независимости от 18 октября 1991 года Парламент Азербайджанской Республики был определен как независимая ветвь власти. В то время Верховный Совет Азербайджана делегировал многие из своих полномочий Национальному совету из 50 членов, который он избрал из числа своих представителей. Таким образом, была создана первоначальная база для формирования нынешнего Милли Меджлиса.

Согласно конституционному закону о Национальном совете от 30 октября 1991 года этот орган должен был состоять из 72 членов. 26 ноября Верховный Совет республики, пересмотрев указанный Конституционный закон, внес поправки в статьи предыдущей редакции, ограничивающие полномочия Совета. Национальный совет был переименован в Национальное собрание. Новый состав Милли Меджлиса был сформирован на паритетных началах. В него вошли 25 представителей демократов и 25 других депутатов.

Члены Милли Меджлиса вели постоянную деятельность и имели право на восстановление в должности. В переходный период полномочия Верховного Совета Азербайджанской Республики были переданы Милли Меджлису республики. В целях обеспечения деятельности Милли Медж- 
лиса был создан Секретариат Верховного Совета республики. До утверждения Положения Милли Меджлиса Республики его деятельность регулировалась временным постановлением Верховного Совета. Таким образом, путем установления в стране общественно-политической стабильности восстановились законность и правовые правила, что привело к созданию необходимых общественно-политических условий для принятия первой в истории азербайджанского народа и государства национальной Конституции.

Так, 12 августа 1995 года был принят Закон «О выборах в Милли Меджлис Азербайджанской Республики». Состав Милли Меджлиса - высшего законодательного органа республики - определяли 125 человек. Выборы в Милли Меджлис сроком на 5 лет проводились по мажоритарной и пропорциональной избирательным системам. Выборы в Милли Меджлис состоялись 12 ноября. Окружные избирательные комиссии были созданы в 99 из 100 одномандатных округов страны. Окружная избирательная комиссия для проведения выборов в Ханкенди-Ходжавенд-Ходжалинском избирательном округе № 42 по понятным причинам не была создана. На основе пропорциональной избирательной системы был создан единый республиканский многомандатный округ для подготовки и проведения выборов.

В среднем 4 кандидата боролись за одно место в парламенте при мажоритарной избирательной системе. В Милли Меджлис Азербайджанской Республики первого созыва были избраны 124 депутата, 99 из которых были избраны по одномандатным округам, 25 - по многомандатным. 69 депутатов принадлежали к политическим партиям, 53 из которых представляли партию «Ени Азербайджан», четверо членов представляли партии «Национальной независимости Азербайджана» и «Народного фронта Азербайджана», по двое - «Демократическую партию Азербайджана» и «Демократическую партию предпринимателей Азербайджана», по одному партии «Демократического просвещения Азербайджана», "Родину-мать», «Партию солидарности» и «Мусават». Количество нейтральных депутатов парламента составило 55 человек. 15 избранных депутатов - женщины [8, с. 446-447; 4, с. 229-231]. Таким образом, в результате выборов в Милли Меджлис Азербайджанской Республики первого созыва был сформирован многопартийный парламент.

В Конституции 1995 года осуществление законодательной власти в соответствии с принципом разделения властей определено как прерогатива Милли Меджлиса Азербайджанской Республики. Никакой орган или лицо, кроме Милли Меджлиса, не имеет полномочий принимать законы. Несмотря на то, что законотворчество определе- но как основная функция Милли Меджлиса, он также обладает функцией контроля и другими. В соответствии с внесенными поправками в Конституцию посредством референдума, состоявшегося 24 августа 2002 года, было отменено совместное применение мажоритарной и пропорциональной избирательных систем и установлено общую мажоритарную избирательную систему.

Выводы. Таким образом, обобщение всех идей, изложенных в этой статье, позволяет сделать определенные выводы:

1. При исследовании института национального парламента необходимо использовать метод исторического подхода, поскольку исследование истории развития Милли Меджлиса:

1) обеспечивает эффективное использование исторического подхода в исследованиях этого института;

2) позволяет национальному парламенту изучить историческую необходимость, оправдывающую возникновение и появление наших традиций;

3) приводит к формированию четкого представления о последующей истории развития национального парламента;

4) создает теоретическую основу для четкого понимания места и роли этого парламентского института в современном обществе и для выдвижения научных представлений о перспективах его дальнейшего развития.

2. После восстановления государственной независимости наш народ столкнулся с рядом важных судьбоносных проблем. Несомненно, центральное место здесь занимала задача построения демократического правового государства. Милли Меджлис, законодательный орган нашего независимого государства, сыграл исключительную роль в успешном решении этой задачи. Таким образом, формирование законодательной базы государственного строительства во всех сферах страны, реформы, проводимые в этом направлении, были связаны с эффективным функционированием указанного выше института.

Без учета исторического развития очень сложно улучшить деятельность Милли Меджлиса и законодательство, регулирующее эту деятельность, в соответствии с требованиями, целями и задачами демократического государства с верховенством закона. Невозможно создать современный институт парламентаризма и определить его дальнейшее развитие без анализа деятельности представительных, совещательных и законодательных органов, ранее действовавших на территории Азербайджана, и норм, регулирующих эту деятельность.

3. Анализ и обобщение истории становления законодательной власти в Азербайджане дает основание сделать вывод, что представительные нормотворческие и законодательные институ- 
ты в Азербайджане прошли в своем развитии такие этапы:

1. Античный и средневековый период - Консультативные советы.

2. Период ханства - Диванные советы.

3. Царский период - Дума.

4. Период АХC - первый демократический парламент.

5. Первый советский период (1921-1937 гг.) Советы рабочих и крестьянских депутатов.

6. Советский период после принятия Конституции 1937 года (1937-1991 гг.) - Верховный Совет;

7. Период независимости (после 1991 г.) - Милли Меджлис.

\section{Лumepamypa}

1. Агамалы Ф.Р. Социально-экономические отношения в ханствах Северного Азербайджана во второй половине 18 - в начале 19 века. Баку : Издательство «Бакинский университет», 2007, 280 с.

2. Агамалиев Н.О. О деятельности Демократического парламента Азербайджана // Азербайджанская Демократическая Республика. Баку, 1992, 123 с.

3. Азербайджанская Демократическая Республика (1918-1920 гг.). https://a-r.az/en/page/44 (дата обращения: 22.01.2021.)

4. История азербайджанского парламентаризма. Во 2-л толе. Том II. Баку : Переводчик, 2018. 680 с.

5. Байрамлы 3.X. Структура и система управления Сефевидского государства Азербайджана. Баку : АДПУ, 2006, 258 с.

6. Джаббаров 3.3. О правовой природе указов в Азербайджане в XV - XVIII веках. Новости Бакин ского Университета. Серия социально-политических наук. Баку, 2005, № 4. С. 74-84.

7. Исламов Т. Из истории парламентаризма Азербайджана. История и ее проблемы. Баку, 2009, № 4 . С. $42-48$.

8. Исмаилов Х.С. Юридическая история Азербайджана. Баку : Наука и образование, 2015, 572 с.

9. Гасымлы М., Мурадова Б., Гафаров В. История азербайджанского парламентаризма. $B$ 2-x mомах. Я сидел. Баку : Переводчик, 2018, 688 с.

10. Гадималиев А.Р. Парламентаризм как конституционно-правовой институт. Актуальные проблемы государственного и правового строительства в Азер байджанской Республике. Сборник научных статей. 18-е издание. Баку : Адилоглу, 2007. С. 92-97.

11. Мирзаев С.А. Развитие и современные функции парламента Азербайджана. Новости Бакинского Университета. Серия социально-политических наук. Баку, 2009, № 3. С. 40-49.

12. Мусаев М. Парламент и крестьяне через 100 лет (1905-2005 гг.). Баку : Нурлар, 2008. 272 с.

13. Пириев В.З. Азербайджан в XIII - XIV вв. Баку : Нурлан, 2003.458 с.

14. Сеидов М.Н. Становление органов государственного управления в Древнем Азербайджане / Актуаль ные проблемы государственного и правового строи тельства в Азербайджанской Республике. Сборник научных статей. 17-е издание. Баку : Адилоглу, 2007. C. $11-20$

15. Дьяконов И.М. История мидян. МЛ : Изд-во АН CCCP $1956,486 \mathrm{c}$.

16. Рзаев А.К. Этюды из истории политико-правовых учений. Баку : Азернешр, 1986, 176 с.

17. Сеидзаде Д.Б. Азербайджанские депутаты в Государственной Думе России. Баку : Азернешр, 1991, $139 \mathrm{c.}$

\section{Аннотация}

Рустамзаде А. Х., Гасанов Э. Э. Исторические аспекты становления и развития парламентаризма. Статья.

Основная цель исследования состоит в анализе исторических этапов становления законодательной власти в Азербайджане. Авторы обосновывают необходимость использования исторического подхода при исследовании института национального парламента, подчеркивают исключительную роль Милли Меджлиса - законодательного органа нашего независимого государства в успешном решении задачи построения в Азербайджане демократического государства, основанного на верховенстве закона. Они различают этапы развития представительского законодательства, законодательных институтов.

Методы. При написании исследования использовались системный анализ, исторический подход к обобщению нормативных научно-практических материалов и другие методы. С помощью общенаучных и частнонаучных методов авторы последовательно проанализировали данные.

Научная новизна статьи. Парламентаризм Азербайджана не ограничивается одной конституционной нормой. История парламентаризма в Азербайджане шире, чем парламентаризм, который определяет конституционные нормы. В 1918-1920 годах в Азербайджане началась история парламентаризма в современном понимании, связанная с образованием и деятельностью Азербайджанской Демократической Республики. 20 ноября 1918 года Национальный совет принял Закон «О Парламенте Азербайджанской Республики», согласно которому представители политических партий и всех проживающих в Азербайджане национальных меньшинств должны были быть представлены в однопалатном парламенте из 120 депутатов.

В заключении исследователи определили, что изучение истории развития Милли Меджлиса обеспечивает эффективное использование исторического подхода в исследовании этого учреждения; позволяет национальному парламенту изучить историческую необходимость, оправдывает появление наших традиций; приводит $\kappa$ формированию четкого представления о дальнейшей истории развития национального парламента; создает теоретическую основу для четкого понимания места и роли этого парламентского института в современном обществе и для продвижения научных представлений о перспективах его дальнейшего развития.

Ключевые слова: законодательная власть, история развития, исторический подход, Совет старейшин, Консультативный совет, Верховная Рада, Национальный совет, Милли Меджлис. 


\section{Анотація}

Русталзаде A. Х., Гасанов E. Е. Історичні аспекти становлення й розвитку парламентаризму. - Стаття.

Основна мета дослідження полягає в аналізі історичних етапів становлення законодавчої влади в Азербайджані. Автори обгрунтовують необхідність використання історичного підходу при дослідженні інституту національного парламенту, підкреслюють виняткову роль Міллі Меджлісу - законодавчого органу нашої незалежної держави в успішному вирішенні завдання побудови в Азербайджані демократичної держави, заснованої на верховенстві закону. Розрізняють етапи розвитку представницького законодавства, законодавчих інститутів.

Методи. При написанні дослідження використовувалися системний аналіз, історичний підхід до узагальнення нормативних науково-практичних матеріалів та інші методи. За допомогою загальнонаукових і частково-наукових методів автори послідовно проаналізували дані.

Наукова новизна статті. Парламентаризм Азербайджану не обмежується однією конституційною нормою. Історія парламентаризму в Азербайджані ширша, ніж парламентаризм, який визначає конституційні норми. У 1918-1920 роках в Азербайджані почалася історія парламентаризму в сучасному розумінні, пов'язана 3 утворенням і діяльністю Азербайджанської Демократичної Республіки. 20 листопада 1918 року Національна рада ухвалила Закон «Про Парламент Азербайджанської Республіки», згідно 3 яким представники політичних партій і всіх проживаючі в Азербайджані національні меншини повинні були бути представленими в однопалатному парламенті зі 120 депутатів.

У висновку дослідники зазначають, що вивчення історії розвитку Міллі Меджлісу забезпечує ефективне використання історичного підходу в дослідженні цієї установи; дозволяє національному парламенту вивчити історичну необхідність, що пояснює виникнення наших традицій; призводить до формування чіткого уявлення про подальшу історію розвитку національного парламенту; створює теоретичну основу для чіткого розуміння місця і ролі цього парламентського інституту в сучасному суспільстві і для просування наукових уявлень про перспективи його подальшого розвитку.

Ключові слова: законодавча влада, історія розвитку, історичний підхід, Рада старійшин, Консультативна рада, Верховна Рада, Національна рада, Міллі Меджліс.

\section{Summary}

Rustamzade A. H., Hasanov E. E. Historical aspects of the formation and development of parliamentarism. Article.

The main purpose of the research study is to analyze the historical stages of the formation of the legislative branch in Azerbaijan. The author substantiates the need to use the historical approach in the study of the national parliamentary institution, emphasizes the exceptional role of the Milli Majlis, the legislative body of our independent state in the successful solution of the task of building a democratic state governed by the rule of law in Azerbaijan. Representative norm-setting distinguishes the stages of development of legislative institutions.

Methods. The systematic analysis, historical approach to the generalization of normative scientific and practical materials and other methods has been used while writing the research. With the help of general and specific scientific methods the author coherently analyzed the data.

Scientific novelty of the article. Parliamentarism of Azerbaijan is not limited to one constitutional norm. The history of parliamentarism in Azerbaijan is broader than parliamentarism, which determines constitutional norms. In 1918-1920, the history of parliamentarism in the modern sense begins in Azerbaijan, which is associated with the formation and activities of the Azerbaijan Democratic Republic. On November 20, 1918, the National Council adopted the Law "On the Parliament of the Republic of Azerbaijan", according to which representatives of political parties and all national minorities living in Azerbaijan were to be represented in a unicameral parliament of 120 deputies.

The researcher defines in the conclusions that study of the history of the development of the Milli Mejlis ensures the effective use of the historical approach in the research of this institution; allows the national parliament to examine the historical necessity that justifies the emergence and emergence of our traditions; leads to the formation of a clear understanding of the subsequent history of the development of the national parliament; creates a theoretical basis for a clear understanding of the place and role of this parliamentary institution in modern society and for the advancement of scientific ideas about the prospects for its further development.

Key words: Legislative power, history of development, historical approach, Council of Elders, Advisory Council, Supreme Soviet, National Council, Milli Majlis. 